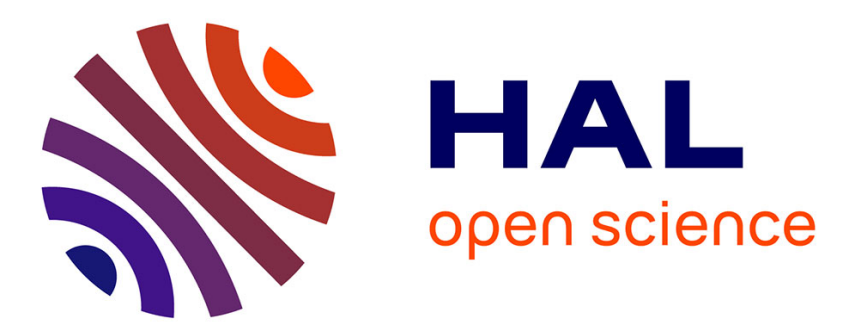

\title{
Phase transition under pressure of two disc-like liquid crystals studied with an accurate automated metabolemeter
}

\author{
J.M. Buisine, B. Soulestin
}

\section{- To cite this version:}

J.M. Buisine, B. Soulestin. Phase transition under pressure of two disc-like liquid crystals studied with an accurate automated metabolemeter. Revue de Physique Appliquée, 1987, 22 (10), pp.1211-1214. 10.1051/rphysap:0198700220100121100 . jpa-00245670

\section{HAL Id: jpa-00245670 https://hal.science/jpa-00245670}

Submitted on 1 Jan 1987

HAL is a multi-disciplinary open access archive for the deposit and dissemination of scientific research documents, whether they are published or not. The documents may come from teaching and research institutions in France or abroad, or from public or private research centers.
L'archive ouverte pluridisciplinaire HAL, est destinée au dépôt et à la diffusion de documents scientifiques de niveau recherche, publiés ou non, émanant des établissements d'enseignement et de recherche français ou étrangers, des laboratoires publics ou privés. 


\title{
Phase transition under pressure of two disc-like liquid crystals studied with an accurate automated metabolemeter
}

\author{
J. M. Buisine and B. Soulestin
}

Equipe de Dynamique des Cristaux Moléculaires, U.A. CNRS 801, Université des Sciences et Techniques de Lille Flandres-Artois, 59655 Villeneuve d'Ascq Cedex, France

(Reçu le 25 février 1987, accepté le 18 mai 1987)

\begin{abstract}
Résumé. - Un nouveau dispositif instrumental de métabolemètre permettant des mesures précises et des expérimentations de routine est présenté. Une nouvelle cellule de mesure de la pression en fonction de la température est décrite. Des exemples d'utilisation pour l'étude des transitions de phase sous pression sont donnés dans le cas de deux cristaux liquides à molécules discoïdes.
\end{abstract}

\begin{abstract}
New instrumentation arrangements for a metabolemeter ensuring accurate measurements and routine experiments are described. Details relative to a new pressure-temperature cell and to its performances are reported. Examples of use for the phase transition studies under pressure are given for two pure disc-like liquid crystals.
\end{abstract}

\section{Introduction.}

Phase transitions of organic compounds, pure or in binary mixtures, can be detected by thermo-barometric analysis (T.B.A.) on using a metabolemeter i.e. by recording, versus temperature, the pressure of a little sample (about $1 \mathrm{mg}$ ) enclosed in a metallic cell [1-4]. However, the experimental procedures for filling up the cell, closing off the apparatus and securing a good thightness are long and complex [1]. Errors in these procedures can involve the destruction of the sensor measuring the pressure [5]. Cause the experiments are performed in a heating and cooling housing, working at constant power, and the temperature is detected only nearness the cell, large uncertainties cast sometimes the temperature measurements [3-4]. More when using an analogic $X-Y$ recorder for plotting the pressure versus temperature, the ad hoc range cannot always be designed from the first experiment. So other ones are necessary that are not always possible when failures under high pressure and/or compounds decomposition at high temperature and pressure occur [5]. We present here new instrumentation arrangements mitigating these disadvantages, allowing more accurate measurements and routine experiments, the performances of the new system and some new experimentals results.

\section{Instrumentation arrangements.}

The pressure-temperature cell (French licence) is shown figure 1. A pressure transducer (1) (HEM $375-20000$-Kulite International) is bonded by an epoxy adhesive film on a steel crucible (2) and is

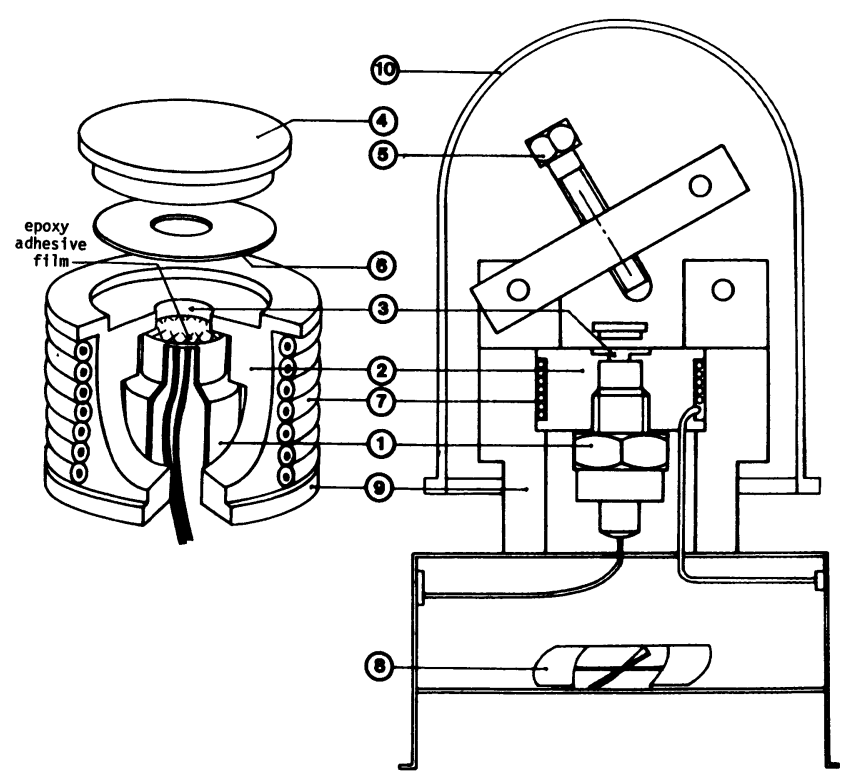

Fig. 1. - Cross-sectional drawing of the present measurement cell. 
used as bottom of the cavity (3) in which the sample is introduced. The cell is closed with a little steel cover (4) and sealed hermetically with a set screw (5). The tightness is insured by a plan annular joint (tin or zinc) (6). This arrangement cancels the pressure transducer destroying risks during the closing of the cell. Heater (Thermocoax) (7) are coiled around the crucible (2). A fan (8) allows the cooling experiments. The temperature is measured with a platinium resistance probe. The cell is placed on a steel stand (9) and insulated from outside with a glass housing (10).

The P.T. cell is connected through interfaces to a computer (Goupil 3, configuration 4, S.M.T.) associated to a graphic plotter (DMP 40, Houston Instrument) and a printer (RX 80, Epson). The computer is used to control the heating and the cooling of the cell, for pressure-temperature acquisitions in data files and for the delete treatment of the data files.

The temperature range is $+25^{\circ} \mathrm{C}$ to $+235^{\circ} \mathrm{C}$; the pressure range is 0 to +1400 bar. The maximal volume of the sample is 2 cubic millimeters. The accuracy for the sample temperature is $0.5^{\circ} \mathrm{C}$ for heating and cooling speeds lower then $2.5^{\circ} \mathrm{C} / \mathrm{min}$. The sensitivity for the pressure measurements is 0.1 bar ; the pressure background is lower than 0.7 bar before data filtering. The lower pressure increment that can be detected at a first order transition is about 5 bar; that corresponds to a transformation with a $0.015 \mathrm{kcal} / \mathrm{mole}$ enthalpy change for a 0.5 $\mathrm{kg} /$ mole molar mass compound. The lower slope change that can be detected between two phases is $0.8 \mathrm{bar} / \mathrm{K}$. These performances (Tab. I) are in agreement with that can be expected for a routine phase transition detection apparatus [5] for new synthetised organic compounds.

\section{Examples of use thermobarograms of disc-like liquid crystals.}

Sensitivity tests have been performed on disc-like liquid crystals. Such compounds exhibit one or several mesophases between the solid and the liquid states. The transitions between the mesophases are very often difficult to observe with an optical microscope and the associated enthalpy changes are too small to be detected by calorimetric measurements on little samples. We present here some results obtained on two of these compounds : (-) 2, 3, 6, 7, 10, 11-hexa-S-(3-methyl)-n-nonanoyloxytriphenylene [(-)C $\left.\mathrm{C}_{10} \mathrm{HAT}\right][6]$ and $2,3,7,8,12,13$, hexa- $n$ decanoyloxytruxene [ $\mathrm{C}_{10}$ HATX] [7].

Figure 2 gives two thermobarograms obtained on heating with a little sample $(1.2 \mathrm{mg})$ of $\mathrm{C}_{10}$ HAT set in the new $P-T$ cell and simultaneously connected to an analogic $X$ - $Y$ plotter (Fig. 2a) and to the compu-<smiles>[R]c1cc2c3cc([R])c([R])cc3c3cc([R])c([R])cc3c2cc1[R]</smiles>
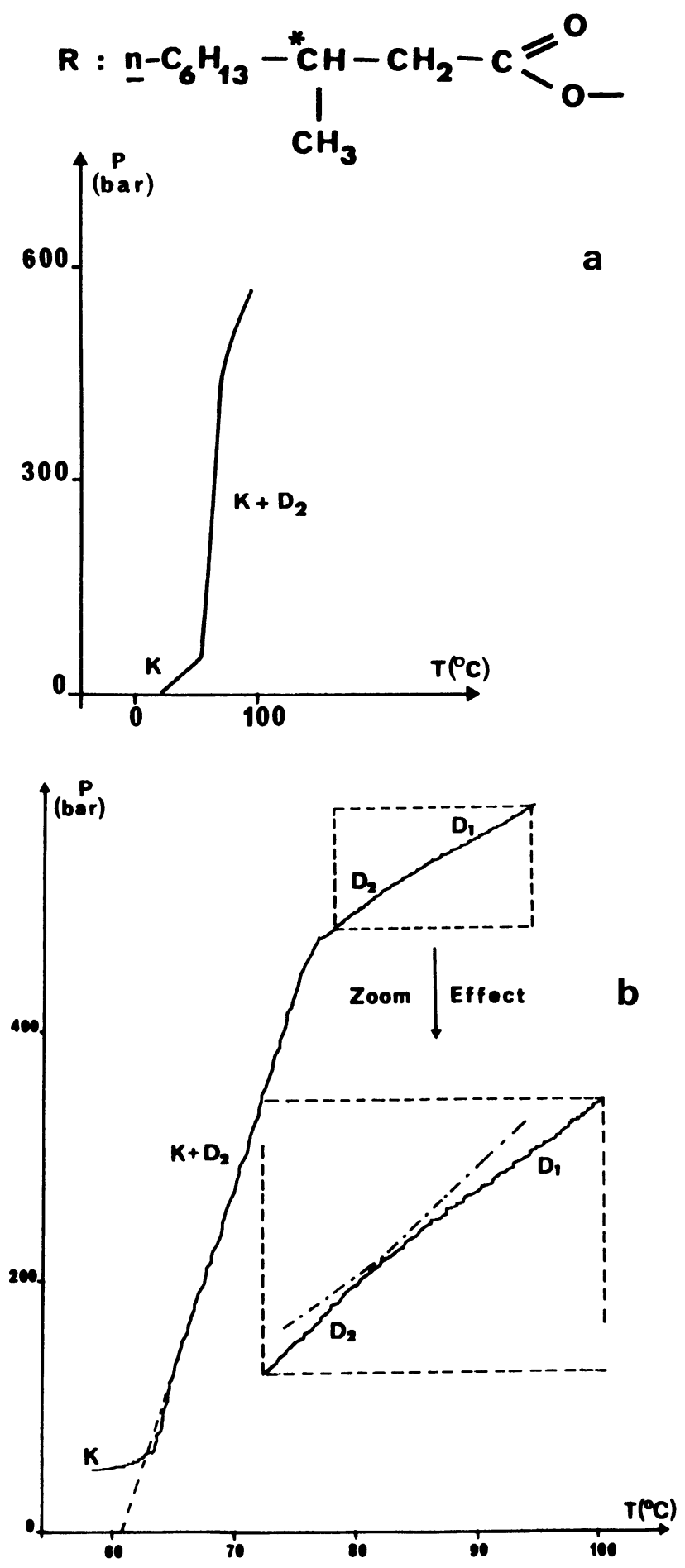

Fig. 2. - Thermobarograms obtained on heating: (a) with an analogical plotter, (b) with the automated system for (-) $\mathrm{C}_{10}$ HAT. 
Table I. - Performances of the automated metabolemeter.

\begin{tabular}{|c|c|c|c|c|c|c|}
\hline $\begin{array}{c}\text { Maximal } \\
\text { sample } \\
\text { volume }\end{array}$ & \multicolumn{2}{|c|}{ Operating ranges } & \multicolumn{2}{c|}{ Accuracy } & \multicolumn{2}{c|}{ Sensitivity } \\
Temperature & Pressure & Sample & Pressure & Pressure & Slope \\
temperature & background & changes & changes \\
\hline $2 \mathrm{~mm}^{3}$ & 25 to $235^{\circ} \mathrm{C}$ & 0 to $1400 \mathrm{bar}$ & $0.5^{\circ} \mathrm{C}$ & $0.07 \mathrm{bar}$ & $5 \mathrm{bar}$ & $0.8 \mathrm{bar} /{ }^{\circ} \mathrm{C}$ \\
\hline
\end{tabular}

ter system (Fig. 2b). On the second thermobarogram the melting (K- $\mathrm{D}_{2}$ transition) is observed at $61{ }^{\circ} \mathrm{C}$ under atmospheric pressure. Under 530 bar and at $86^{\circ} \mathrm{C}$ a change of slope appears relative to a transition between two mesophases $\left(D_{2}-D_{1}\right.$ transition); that transition can be considered as weakly first order or second order; a zoom effect (Fig. 2b) lets no doubt about this change of slope. On the first thermobarogram such change of slope cannot be detected due to the wrong choice of both temperature and pressure ranges that demonstrate the advantage of the automated system. Data that can be deduced from several experiments for all the transformations of (-) $\mathrm{C}_{10}$ HAT are reported on the table II.

For $\mathrm{C}_{10}$ HATX ( $2 \mathrm{mg}$.sample) a thermobarogram obtained on cooling with the automated system is reported in figure 3 . Three transformations between mesophases are detectable : at $121^{\circ} \mathrm{C}$ under 512 bar: the $D_{h}-D_{r d}$ transition (change of slope), at $104{ }^{\circ} \mathrm{C}$ under 430 bar : the $\mathrm{D}_{\mathrm{rd}}-\mathrm{N}_{\mathrm{D}}$ transition (13 bar pressure change), at $72{ }^{\circ} \mathrm{C}$ under 265 bar: the $\mathrm{N}_{\mathrm{D}}-\mathrm{D}_{\mathrm{R}}$ transition (change of slope). That last transition is not observed under atmospheric pressure [7] ; it corresponds to the appearance of a reentrant pressure induced mesophase $D_{h}[8]$.

In summary we have designed new arrangements for a metabolemeter that ensures pressure transducer

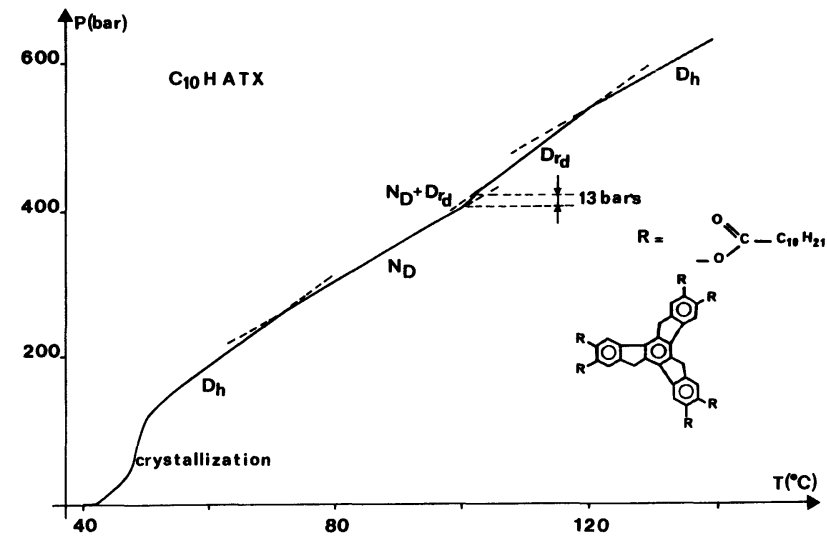

Fig. 3. - Thermobarogram obtained on cooling for $\mathrm{C}_{10}$ HATX.

destroying risk, better performances for the temperature measurements and for the detection of phases transitions. That unified automatic system is suited for routine studies of organic compounds under pressure.

\section{Acknowledgments.}

The authors would like to thank the M.T.M. Leader company who helped them in designing the measure-

Table II. - Literature and experimental data for the transitions and the phases of (-) $\mathrm{C}_{10} \mathrm{HAT}$.

\begin{tabular}{|c|c|c|c|c|c|c|c|c|}
\hline \multirow[b]{2}{*}{ Transition température $\left({ }^{\circ} \mathrm{C}\right)$} & $\begin{array}{c}\text { Crysta } \\
\text { K }\end{array}$ & & $\begin{array}{c}\text { Meso- } \\
\text { phase } \\
\mathrm{D}_{2}\end{array}$ & & $\begin{array}{c}\text { Meso- } \\
\text { phase } \\
D_{1}\end{array}$ & & $\begin{array}{l}\text { Liquid } \\
\text { I }\end{array}$ & Références \\
\hline & & $\begin{array}{l}59 \\
61\end{array}$ & . & 64.5 & . & 97.5 & • & $\begin{array}{l}{[6]} \\
(*)\end{array}$ \\
\hline Enthalpy change ( $\mathrm{kcal} / \mathrm{mol})$ & & 5.9 & & 0.016 & & 1.06 & & [6] \\
\hline $\begin{array}{l}\text { Slope of equilibrium curves } \\
\text { under atmospheric pressure } \\
\text { (bar/K) }\end{array}$ & & 29.6 & & 21 & & 26.1 & & $(*)$ \\
\hline Volume change $\left(\mathrm{cm}^{3} / \mathrm{mole}\right)$ & & 25.09 & & 0.094 & & 4.58 & & $(*)$ \\
\hline $\begin{array}{l}\text { Ratio thermal expansion/iso- } \\
\text { thermal compressibility for the } \\
\text { phases (bar/K) }\end{array}$ & 16.6 & & 7.1 & & 5.5 & & 3.5 & $\left(^{*}\right)$ \\
\hline
\end{tabular}

(*) This work. 
ments cell, G. Freville, J. M. Lefranc and G. Buche for assistance in automatizing the apparatus, and

Note : the automated metabolemeter is now manufactured and distributed under the reference MAB 02 by M.L.M. LEADER, 2 rue de la Créativité, B.P. 33, 59651 Villeneuve d'Ascq Cedex.
J. Malthete, C. Destrade and Nguyen Huu Tinh for providing liquid crystals samples. The automated metabolemeter has been developed from an A.N.V.A.R. contract $n^{\circ}$ A83-09-084-N066.

\section{References}

[1] Buisine, J. M., Soulestin, B. and Billard, J., Mol. Cryst. Liq. Cryst. 91 (1983) 115.

[2] Buisine, J. M., Soulestin, B. and Billard, J., Mol. Cryst. Liq. Cryst. 93 (1983) 397.

[3] Buisine, J. M., Mol. Cryst. Liq. Cryst. 109 (1984) 143.

[4] Buisine, J. M. and Billard, J., Mol. Cryst. Liq. Cryst. 127 (1985) 353.

[5] Buisine, J. M., Thèse (1984) Lille.
[6] Destrade, C., Nguyen Huu Thinh, Malthete, J. and JACQues, J., Phys. Lett. 79A (1980) 189.

[7] Nguyen Huu Thinh, Foucher, P., Destrade, C., Levelut, A. M. and Malthete, J., Mol. Cryst. Liq. Cryst. 111 (1984) 277.

[8] Buisine, J. M., Cayuela, R., Destrade, C. and NGUYen HuU Thinh, to be published in $M o l$. Cryst. Liq. Cryst. 